\author{
Olena Orlenko, \\ Doctor of Economics, Professor, \\ Kherson State University, Ukraine, \\ 27, Universitetska str., Kherson, 73000, Ukraine, \\ ORCID: 0000-0002-3485-1642; \\ ResearcherID: AAH-9447-2020
}

\title{
THE ANALYSIS OF TOURIST PREFERENCES IN SOUTHERN UKRAINE
}

The article deals with the analysis of tourist preferences in the Southern region of Ukraine. The author researches a current state and economic rationale of the development of the restaurant business in Southern Ukraine taking into account the peculiarities of its formation and development worldwide as well as to determine main trends in the restaurant business in the near-term outlook. The author underlines that nowadays consumer service sphere of resorts in the Southern region is represented by a wide range of establishments specializing in various services. Dining outlets serve different groups of tourists and that's why it is necessary to use individual and specific methods and techniques of services. The author concludes that resort restaurants need to pay attention to local producers who can be competitive due to the lower prices as they are located closer to the end-users. The use of local trends in brand names and advertising, proper price policy - all these are strategies which help a local producer to work successfully in the regional market and even replace international brands. Restaurateurs and local producers can benefit due to the minimization of middle men's amount offering goods and services directly to the customer.

Keywords: hospitality, restaurant business, Southern Ukraine, tourist preferences.

Relevance of research topic. Today's world deals with the instability in all spheres of our life. Global changes and downturns all over the world remind us about the necessity of urgent modifications, especially in our minds. In the context of the evolution of the modern civilization, it is necessary to develop and realize a human's creative potential that is caused by such trends as the escalation of conflicts in society and nature relationships, the information revolution, and transition to post-industrial society, globalization, etc. Along with certain progressive consequences and advantages for humanity, civilizing processes brings new unsafe transformations, requires creative searches, efficient social technologies to cope with their negative effects. But the processes occurring in the modern world are connected with the search 
of the further spiritual development of the society. They require new looks at all sphere of life drawing on the people's spiritual and intellectual potential and provide the development of each person's creative abilities.

Over the last years, domestic tourism is rapidly gathering momentum and the hospitality industry is attuned to these needs. One of its integral parts is the restaurant industry influencing the country's social and economic growth. The southern region is attracting the attention of connoisseurs of antiquity with its rich historical past; tourists can focus their attention on original world-known recreational facilities, the Black and Azov Sea resorts. So it is especially important to provide a high-level recreation.

Formulation of the problem. In more than 40 countries of the world, tourism is the main source of revenues for the state budget. Traditionally Southern Ukraine has a great potential in this sphere as well as in many others but it has inefficient and conflicting regulation at all levels. Southern Ukraine has all the conditions for this: the geographical location, the availability of huge amount of cultural and natural resorts, relatively small but developed tourist infrastructure with 1400 accommodations, natural resorts some of which have unique healthcare facilities - Genichesk, Skadovsk, Arabat Spit, Kherson Mountains of Baidiha canyon (Stanislav), Askania-Nova, Kinburn Spit, Oleshky Pisky etc. That's why having such natural and cultural facilities, tourism should have more attention while forming and realizing the state policy in this filed.

The developed restaurant business is an integral part of the hospitality process. It is a profitable economic sector of the country. It not only serves the customers but represents the country on the international market. Dining outlets in the therapeutic facility areas serve various groups of tourists for natives and foreigners, package and independent tours. While serving the tourists, a restaurant business plays an important role and acquires some specific features to consider such a business as a part of the tourism industry.

No doubt that a restaurant business is to be adaptable to rapid modern trend satisfying needs of not only native but foreign tourists too. Tourist traffic is also important as well as factors influencing them. No less important is to follow the food preferences of the increasing tourist traffic of foreign guests. First of all, such an approach should be used in the hotel restaurant as well as in those located in the therapeutic facility areas.

Analysis of recent researches and publications. A lot of native and foreign scientists emphasize different aspects of the hotel business development: N. O. Piatnytska, O. D. Timchenko, O. P. Tkachenko, M. V. Chorna, N. N. Mitsenko, S. M. Bezrodna, S. M. Shamara, O. P. Butenko, T. V. Shtal, E. B. Gheribi, E. K. Kwiatkovska, G. O. Levytska [1-15].

Mentioned above authors research different segments of the restaurant business, determine upcoming trends and negative and positive factors influencing the restaurant 
business. Thought this service sector is of great importance and has an important role in the economy, many experts think the restaurant business to be on the nascent stage. So there is a problem in searching a developing path and efficiency improvement of the restaurant businesses. Despite some remarkable works in this field, there are some aspects such as the hospitality industry modern state, its demand for services and progress trends are a topic for further scientific investigation.

As to the statistical data, Southern Ukraine restaurateurs focus on national and Italian cuisine as well as barbecue dishes. As analysts report among 14 thousand of the restaurants almost $80 \%$ offers Ukrainian national dishes, about $73 \%$ has Italian cuisine on the menu and $45-50 \%$ serves barbecue and grill [2].

Around $20 \%$ offers Georgian cuisine that is popular in Southern Ukraine. Japanese cuisine covers $16 \%$ of the restaurants. $4 \%$ of all the restaurants have author's cuisine and the same amount is for such exotic cuisines as Chinese, Asian, American and vegetarian facilities. Some menu options such as pasta, pizza, steaks, grill dishes, Greek salad and cheesecake can be found in any restaurant [20].

Presenting main material. The crisis pushes restaurants to be multipurpose. Mentioned above menu options are the most popular ones in the majority of the restaurants: they do not require expensive or rare ingredients. But this format is fraying around the edges.

Nowadays there are changes in consuming in the restaurant services. The new trend is the promotion of national cuisine: Ukrainian cuisine cooked from Ukrainian food. There are also some groups representing the cuisines of different Ukrainian regions. For a while, there were a lot of national restaurants but some heavy, not authentic dishes were served there. Today there are restaurants where it is possible to taste amazing dishes from different regions of our country: restaurants of Podolia cuisine, Carpathian cuisine, Bessarabian cuisine. The restaurants emphasize national dishes - Bessarabian cuisine and wines. They work only with local food and cook dishes using authentic recipes.

One of the Sothern Ukraine regions is Kherson region which has a unique area for tourism, rest and recreation. It is one among all regions of Ukraine which is washed by two seas - the Black Sea and the Azov Sea. The coastline is about 200 kilometres and it has wonderful sandy beaches, developed recreational infrastructure in 11 resorts. Specifically, here you can find:

- the biggest fresh water-storage basins in Kakhovka;

- ecologically friendly and unforgettable recreational site Dnieper Delta - one of the biggest plavni (reed marches) area in Europe;

- the longest sand spits in the world - Arabatska Strilka;

- the biggest desert island in Europe - Dzharylhach;

- the only natural desert in Ukraine, one of the biggest sands in Europe Oleshkivski Pisky; 
- the biggest artificial forest in the world - 100 thousand hectares;

- more than 70 explored balneological resorts with high potential (mineral and thermal water, therapeutic mud, salt lakes, etc.) [16-20].

Kherson region is an ecologically clean area with nature reserves: about 80 sites of national, international and local significance. Among them, there are 2 worldknown biosphere reserves - Chornomorskyi (the Black Sea) and «Askania-Nova» which are submitted to UNESCO. The genuine tourist attractions are four national natural parks: «Azov-Sivash», «Oleshkivski Pisky», «Dzarylhach», and «Lower Dnieper National Nature Park». Besides natural resources, Kherson region is full of more than five thousand historical, cultural and artistic heritage (legendary Kam'yanska and Oleshkivska Sich, Scythian burial mounds, ancient settlements, Turkish fortification ruins, Cossack crosses, numerous churches and cathedrals). There are nautical, green tourism, enotourism (wine tourism), ecotourism, cultural heritage tourism in the region $[10,11]$.

Kherson region is no less famous in the agricultural sphere. Thus, there is a fact that the first oyster farm in Ukraine is located in Kherson region. According to historical data in the XIX century, Ukraine was a famous large exporter of oysters, well-known all over the world. This gourmet item was grown in our area and it was pretty successful. Nowadays Skifian Oysters Company [5] grows oysters on the Black Sea coast in an ecologically clean place of Kherson region, near Chornomorskyi (the Black Sea) biosphere resort submitted to UNESCO. The company cooperates with the National Academy of Sciences of Ukraine which is conducting scientific research there. These oysters are known to have soft meat with delicate marine aroma and sweet nutty aftertaste. According to the company data, they can supply $99 \%$ of oysters for the Ukrainian market. Ukrainian oysters are not worse than foreign ones and the advantage is that Kherson product can be delivered to any place in Ukraine within 5-7 hours. It is widely used by Kherson and regional restaurants which cooperate with the company.

In the south of the country, the important factor for a restaurant business is seasonal fluctuation as the duration of the swimming season is 3-3.5 months on average. The vacation season opens on May 20 and finishes at the end of September. By polling and monitoring, it is determined that the number of available bed spaces (urban-type settlements Zaliznyi Port and Lazurne, the city of Skadovsk) is flexible; the traffic at private accommodations, hotels, and other facilities is changeable.

The maximum growth is in the middle of July and August. It is connected with such factors: school holidays, vacations, favourable weather conditions. There were conducted some researches among tourists of different age, sex, etc. to define the demand for goods and services of restaurants businesses (urban-type settlements Zaliznyi Port and Lazurne, the city of Skadovsk). 
Food services in the resorts can be divided- into three groups: 1) full board 3-4 meals a day (breakfast, lunch, linner, dinner); 2) half-board - 1-2 meals a day (breakfast, dinner); 3) individual - kitchen, kitchenette or other facilities for cooking by themselves.

Among the respondents about 35\% had a rest in the facilities of hotel and catering business where they were able to have a meal in the canteens, cafes (full or half-board), the rest had accommodations in private houses $(65 \%)$ and had to look for eating facilities by themselves.

It is found out that among those who live in the private accommodations, the majority of the respondents (79\%) use the facilities of the hotel and catering business (canteens, cafes, etc.), and others (21\%) prefers homemade food and cooks by themselves. We determined the factors influencing a sales slowdown for goods and services of the hotel and catering business in resorts. Essential factors are the following: high prices, improper working hours, poor choice and quality, bad service.

The majority of respondents negatively evaluate the work of the majority of hotel and catering business facilities but the most negative opinions are about pricing $(42 \%)$, poor choice $(33 \%)$, goods and services quality $(25 \%)$, and improper working hours $(3.5 \%)$.

The customers evaluated service culture using the following parameters: wait time, cleanliness of premises, staff neatness, staff attitude towards customers, kitchen sanitation.

The most negative opinion is about street food stalls selling fast food. The absence of sanitation, bad food technology, and poor food quality cause some negative effects in most cases (food poisoning, digestive disorders, etc.). The only advantage is the quick service. The average rate is 2.94 .

The situation cannot be considered better with canteens and cafes. The average rate for canteens and cafes is 3.68 and 3.92 correspondently. Here the challenge is staff attitude toward customers and kitchen sanitation. The majority of customers do not satisfy with the crockery and cutlery cleanliness. They complained about food leftovers on the crockery and cutlery, dishwashing liquid spots on the cutlery, greasy dishware, coffee and tea stains on mugs, etc. These violations are pretty critical as they do not meet sanitation requirements for dining outlets.

Unskilled staff and seasonal job cause incompetence and poor service in dining outlets. That's why the management of these establishments should change an approach while recruiting: hire employees carefully and thoughtfully, do training, cooperate with educational institutions which train future specialists in the customer service sphere.

The question of dish choice and its quality is also pretty important. About $33 \%$ of the respondents are not satisfied with poor dish choice: starters (about $10 \%$ of all dishes) are represented by 2-3 kinds of salads from seasonal vegetables; first courses 
(about 10\%) are limited with borshch, solianka, and a vegetable soup; main courses (about 60\%) are mainly plov, pelmeni, varenyky, pizza, etc. (easy and fast dishes); sweets (about 5\%); hot (coffee, tea) and cold drinks are mainly not home-made (juices, sodas, etc.); confectionery is represented by non-homemade products.

The choice for starters, first and main courses are natural for establishments with a complete production cycle which offers some adequate nutrition. But there are few such dining outlets. Mainly they are health and recreational resorts canteens, hotel restaurants and cafes. These dining outlets serve limited groups of customers, only those who accommodate there. The majority of dining outlets is pre-prepared meals facilities and does not have an opportunity for some adequate nutrition. The possible solution may be a factory-kitchen or public canteens and fast-food restaurants [3].

Our research shows that $74 \%$ of the respondents want to get one of the meals: $17.2 \%$ needs breakfast, $64.3 \%$ - lunch and 3.5\% - dinner. About $15 \%$ has no opinion; $16.2 \%$ of the respondents want to get 2 meals a day: breakfast and lunch or lunch and dinner.

We also conducted a questionnaire survey as to the prices for the meal. While polling we offered to tell the price which our respondents are ready to pay for the set menu. As we found out, about $2 \%$ think that a proper price is up to $70 \mathrm{UAH}, 3 \%-$ more than $200 \mathrm{UAH}$ and the majority of the respondents think the best price is from 100 to $150 \mathrm{UAH}(45 \%)$ and from 150 to $200 \mathrm{UAH}(36 \%)$. This price is considered to be the best and meets the quality of the given services.

Analysing this data, we can confirm that the best price for breakfasts is from 50 to $70 \mathrm{UAH}$, lunches - 70-120 UAH, dinner - up to $200 \mathrm{UAH}$. Researching the prices in available dining outlets we found out that the price for the set menu is from 120 to $150 \mathrm{UAH}$. But the disadvantage is there are not enough dining outlets which provide set menus to satisfy all needs. All mentioned above tells us about the main problems of the fluctuation of consumer's demand for goods and services of dining outlets in resorts.

Summarizing all the results, we can say that the chaotic work of dining outlets causes low demand level. The task of each enterprise is to get maximum profit. That's why it is strategically important to mind these critical needs. They are opportunities for enterprises to produce and sell more, hence to increase their market share.

Conclusion. This day resort restaurants need to pay attention to local producers who can be competitive due to the lower prices as they are located closer to the endusers. The use of local trends in brand names and advertising, price policy, influence on local retailers - all these are strategies which help a local producer to work successfully in the regional market and even replace international brands. Restaurateurs and local producers can benefit due to the minimization of middle men's amount offering goods and services directly to the customer. 
Tourists visiting the Southern region including Kherson spend more and more money for buying local farm food and culinary (food) tourism are on-trend. Products sold in the fests and produced by local businesses are getting more and more popular.

The social and cultural impact of tourism on society is hard to underestimate. The positive impact of tourism is obvious for low living standards of the local population and high level of unemployment especially among the youth; low rates of construction of housing, social infrastructure facilities; poor conditions of water supply, electric power, heating systems; the lack of skilled employees, etc. Next positive impact of tourism is the governmental programmes for basic, adult and further education. This problem concerns academic programmes as well. But the most critical issue is adult education. It concerns those who are going to work in the hospitality industry as well as experts of governmental structures and local authorities whose sphere of expertise is to plan and to improve national tourism. So it is necessary to shape the tourism policy of Ukraine reflecting organizational, economic, institutional, social and psychological mechanisms to increase tourist traffic in our country. All national tourism policy is to be shaped beginning with the local authority level, with regional development strategy.

It is also possible to conclude that nowadays consumer service sphere of resorts in the Southern region is represented by a wide range of establishments specializing in various services. Dining outlets serve different groups of tourists and that's why it is necessary to use individual and specific methods and techniques of services. But there are also obvious disadvantages being corrected and changed. Despite this fact, the market for health resorts services is potentially attractive therefore it is necessary to provide several approaches to improve it and to maximize its benefits.

To improve customer service sphere in the Southern region it is necessary to stimulate the best companies in HoReCa (hotel, restaurant, and catering) sphere, to promote awards for local brands, to make top lists with the best representatives of the branch, etc. The feedback with tourists, regular monitoring of opinions and reviews allow keeping the eye on the advantages and disadvantages of the market to be able to increase tourist traffic and tourist's average purchase amount as well as tourist's duration of stay.

\section{REFERENCES}

1. Butenko, O. P. (2013). Analysis of the restaurant market economy of Ukraine and prospects for its development. Economical Space, (74), 73-81. 12.

2. Kosova, T. D. (2012). Organization and method of economic analysis. Kyiv: Center for Educational Literature.

3. Kovalenko, N. O. (2015). Analysis of the market of sanatorium and resort services of Ukraine. The Economics of the Food Industry, 7(4), 74-79. 
4. Mitsenko, N. G. (2012). Trends in the development of demand for food products and goods turnover of the restaurant industry. Trade, Commerce, Entrepreneurship: Sb. Sciences Works, (14), 66-69.

5. Mitsenko, N. G. (2014). The restaurant industry as a channel for the sale of agroindustrial complex products. Business-Inform, (4), 208-2014.

6. Orlenko, O. V. (2016). The importance of tourism in the development of the national and world economy. Market Infrastructure, (2), 84-88.

7. Pyatnitskaya, G. T. (2004). Market restaurant economy in Ukraine: the current state and prospects of development. Economist: Sb. Sciences Works, 4, 57-61.

8. Regional program of tourism and resorts development for 2019-2021. (2019, June 4). Retrieved February 3, 2020, from https:/visitkherson.gov.ua/ regionalni-programi/programa-rozvitku-turizmu-ta-kurortiv-u-xersonskij-oblasti-na2019-2021-roki/

9. Shamara, I. M. (2013). Trends in the development of the restaurant industry as a part of the tourism industry of Ukraine. Visnyk Kharkivskoho Natsionalnoho Universytetu Imeni V. N. Karazina, 1(1042), 151-153. Retrieved March 18, 2020, from http://nbuv.gov.ua/UJRN/VKhMv_2013_1042_1_35

10. Stahl, T. V. (2011). Marketing strategies of restaurant enterprises. Kharkiv: KHDUKT.

11. Tkachenko, T. I. (2009). Sustainable tourism development: theory, methodology, business realities. Kyiv.

12. UNWTO World Tourism Barometer and Statistical Annex. (2020, January). Retrieved March 18, 2020, from http://www.unwto.org 